\title{
PARASITOLOGICAL ASPECTS AND BIOCHEMICAL CHANGES OF INFECTED CULTURED TILAPIA (OREOCHROMIS HYBRID)
}

\author{
Maha F.M. SOLIMAN*, Nahla S. EL-SHENAWY, Mahi A. GHOBASHY \\ Zoology Department, Faculty of Science, Suez Canal University, Ismailia, Egypt
}

Soliman M.F.M., El-Shenawy N.S., Ghobashy M.A., 2004. Parasitological aspects and biochemical changes of infected cultured tilapia (Oreochromis hybrid). Acta Ichthyol. Piscat. 34 (1): 21-32.

Background. Fish farming has been developed due to decline of traditional fishing where tilapia culture is one of the principal sources for fish production. This study was aimed to investigate the prevalence and impact of helminth infection on the health of cultured hybrid tilapia, Oreochromis sp.

Material and methods. Prevalence and intensity of helminth infection and histopathological response of infected organs were studied. Changes of biochemical composition, protein electrophoritic pattern, and heavy metals levels of liver and muscle tissues were determined.

Results. Helminth infection was restricted to the liver of $60 \%$ of the examined fish. Of this number $33 \%$ were infected by undifferentiated nematode larvae and heterophyid metacercariae while $67 \%$ showed the metacercarial infection only. Infection caused a noticeable alternation in histological architecture of the liver that was accompanied by depletion in hepatic glycogen, total lipids, and total protein. Moreover, biochemical components of the muscle tissues were significantly decreased along with intensity of infection. Protein fractions of the liver and muscle tissues were highly variable. Intensity of the parasitic infection was directly correlated with $\mathrm{Fe}$ and Mn levels in both liver and muscle.

Conclusions. Cultured fish also suffered from helminth infection that significantly impaired the health and condition of fish as shown by histopathological, biochemical, and protein fractions changes recorded in this study. In additions, intensity of helminth infection might increase the capacity of infected organs in accumulation of heavy metals.

Key words: fish farm, hybrid tilapia, helminthes, histopathology, biochemistry, heavy metals.

\section{INTRODUCTION}

Fish farming has been developed due to decline of traditional fishing because of overfishing, pollution, and consequently the increasing demand for high-quality seafood for population growth and health-related considerations. In Egypt, the culture of tilapia and their hybrids is one of the principal sources for fish production.

\footnotetext{
* Correspondence: maha_soliman@hotmail.com
} 
Tilapia has been classified as "disease resistant", and with a minimal presence of pathogens (Popma and Masser 1999). Man-made pollutants and / or intensification of fish culture resulted in an increase of environmental changes, which may be stressful to fish (Lio-Po and Lim 2002). These conditions can result in decreased resistance by the fish, causing spread of disease and parasite infection (Rottmann et al. 1992). Among fish parasites, the helminthes constitute the major threat to the fish health. It has been suggested that some species of parasite are able to accumulate higher concentrations of trace metals than their host (Sures et al. 1997, Zaghloul et al. 2001).

Publication and reports are available on disease of feral and cultured fish in warm fresh water (Kabata 1985, Lim 1990, 1991, Paperna 1991, 1996, Arthur and Lumanlan-Mayo 1997, Fijan 1999) but few were dealing specifically with pathological response to parasitic disease in aquaculture fish and on the possibility of heavy metals bioaccumulation and their impact on fish health. The influence of parasites on host condition is a central problem in evolutionary biology and parasitology (Esch and Fernandez 1993). In this regard, little is known about normal physiology of cultured tilapia and their response to disease (Hrubec et al. 2000). Although, in Egypt, there has been a number of records of parasitic disease of cultured fish, they were mainly descriptive (Zaghloul et al. 2001).

Therefore, it is necessary from a public health viewpoint to estimate difference source of stress on cultured fish, hence, this work was aimed at investigating the prevalence of natural helminth infection and its impact on histopathological and biochemical response of cultured Oreochromis sp. In addition, heavy metal levels were considered.

\section{MATERIAL AND METHODS}

One hundred and fifty individuals of hybrid tilapia, Oreochromis sp., were collected from a farm in Ismailia, Egypt during spring of 2003. The animals were packed in ice and brought to the laboratory on the same day. Total length and weight of the animals were measured. There was no significant difference regarding the length and weight $(10.9 \pm 2.53 \mathrm{~cm}$ and $182 \pm 19.8 \mathrm{~g}$, respectively).

For parasitological examination, the muscles, liver, kidney, and the intestine of fish were taken then left in saline solution for few minutes, cut into small pieces, compressed between glass plates, and examined under a binocular dissecting microscope. Diameters of the metacercariae found in the compressed slides were measured using a micrometer eyepiece and recorded as the mean value of two measurements.

For histopathological examination, infected organs were immediately removed out from fish, fixed in $10 \%$ buffered formalin, embedded in paraffin, cut at 5- $\mu \mathrm{m}$ sections, and stained with haematoxylin and eosin. Detection and visual evaluation of hepatic glycogen were carried out by using Periodic acid Schiff's (PAS) technique. The intensity of parasitic infection was determined by counting the parasites in an area equal to $1 \mathrm{~mm}^{2}$ in stained paraffin sections. 
The total protein content was determined in wet homogenate liver and muscles tissues using Diamond diagnostics kit (BioMerieux, France). Total lipid content was extracted from tissue using a chloroform-methanol mixture $(2: 1)$ and were determined according to Smedes and Thomasen (1996) using Diamond diagnostics kit. Glycogen content was measured by anthrone reagent as described by Carroll et al. (1956). Results were expressed in $\mathrm{mg} \cdot \mathrm{g}^{-1} \mathrm{w} . \mathrm{w}$. (wet weight).

For electrophoresis analysis, $0.5 \mathrm{~g}$ of the raw fish liver and muscle were homogenized with $4 \mathrm{ml}$ of $2 \%$ SDS extraction solution (2\% sodium dodocyle sulphate, $5 \%$ mercaptoethanol, and $60 \mathrm{mM}$ Tris- $\mathrm{HCl} \mathrm{pH} \mathrm{8.0)} \mathrm{(Etienne} \mathrm{et} \mathrm{al.} \mathrm{1999).} \mathrm{The}$ homogenates were centrifuged $\left(20000 \mathrm{rpm}, 15 \mathrm{~min}, 20^{\circ} \mathrm{C}\right)$ and the supernatants were collected. Solutions of samples and the molecular weight marker proteins were applied to the gel according to the protocol provided by Mackie et al. (2000). Analytical SDS-PAGE separations were performed on gel containing $7 \%$ polyacrylamide. The protein bands were visualized by staining the gel with Coomassie $\AA$ brilliant blue (CBB), then rinsed in destaining solution (ethanol : acetic acid : water $=50: 16: 143$ ) until the background become clear except the blue protein bands. Finally, the gel was preserved in $7 \%$ acetic acid and photographed. Standard protein marker consisted of myosin H-chain (209 KDa), phosphorylase b (112 KDa), bovine serum albumin (83.1 KDa), gultamic dehydrogenase (55.5 KDa), ovalalbumin (49.7 KDa), carbonic anhydrase (31.7 KDa), trypsin inhibitor $(21.5 \mathrm{KDa})$, lysozyme $(17.5 \mathrm{KDa})$ and they were purchased from Merck, Darmstadt, Germany. The acquired images of the gels were analysed with the Whole Band Analyser software of Bio-Image, version 3.3.

$\mathrm{H}_{2} \mathrm{SO}_{4}-\mathrm{HNO}_{3}$ (Merck) acidic mixture (2:3) was used for the digestion of liver and muscles tissues for $\mathrm{Co}, \mathrm{Cu}, \mathrm{Ni}, \mathrm{Fe}$, and $\mathrm{Mn}$ determinations (Hamza-Chaffai et al. 1999). Metal concentrations in the samples were measured using a Perkin Elmer AS 2380 flame atomic absorption spectrophotometer and results were expressed in $\mu \mathrm{g} \cdot \mathrm{g}^{-1}$ w.w. Detection limits found with this method for the analysis of tissues were: $0.2 \mu \mathrm{g} \cdot \mathrm{g}^{-1}$ for $\mathrm{Fe}, 0.1 \mu \mathrm{g} \cdot \mathrm{g}^{-1}$ for $\mathrm{Mn}, 0.04 \mu \mathrm{g} \cdot \mathrm{g}^{-1}$ for $\mathrm{Ni}$, and $0.05 \mu \mathrm{g} \cdot \mathrm{g}^{-1}$ for $\mathrm{Cu}$. A comparison between the amount of heavy metals when added either before or after digestion revealed that there was no loss of the metals during the digestion process with a recovery value of $100-102 \%$ for all the heavy metals. All reagents were from Merck, Darmstadt (Germany).

All processing of data was conducted with the software packages Microsoft Excel XP (for data storage) and SPSS version 10.0, for statistical evaluation. Kruskall-Wallis one way ANOVA was used to compare data. Spearman's rank correlation coefficient was used to test for associations between heavy metals concentration and intensity of parasite infection in the fish tissue.

\section{RESULTS}

The helminth infection was restricted to the liver of $60 \%$ of the examined fish (with no parasites in the other examined tissues). Parasites were mainly heterophyid 
metacercariae and undifferentiated nematode larvae. The infected fish showed mixed infection in $33 \%$ of cases while $67 \%$ were infected only with metacercariae (single infection).

Metacercariae were rounded, yellowish-brown with black pigmentations and different in sizes that related to different developmental stages; no organs were found (Fig. 1).

Mean diameters of metacercariae recovered from single- and mixed-infected fish were summarized in Table 1. Diameters of metacercariae of mixed-infected fish were significantly higher as compared to those of single infection $(P<0.05, F=7.9)$. Intensity of metacercariae per $\mathrm{mm}^{2}$ of liver tissue was higher in case of mixed infection $(P<0.01, F=10.2)$ where more than $60 \%$ of fish had more than three metacercariae per $1 \mathrm{~mm}^{2}$. The intensity of infection with undifferentiated nematode larvae was $0.9 \pm 0.04 \mathrm{spec}$. per $\mathrm{mm}^{3}$ of the liver (Table 1 ).

Table 1

Summary statistic of sizes of heterophyid metacercariae and intensity of helminth infection in liver of hybrid Oreochromis sp.

\begin{tabular}{ccccc}
\hline \multicolumn{2}{c}{ Type of infection } & Parameter & $\bar{x} \pm s$ & Range \\
\hline \multirow{2}{*}{$\begin{array}{c}\text { Single } \\
\text { infection }\end{array}$} & $\begin{array}{c}\text { Heterophyid } \\
\text { metacercariae }\end{array}$ & Diameter $\mu \mathrm{m}$ & $48.7 \pm 4.49$ & $31.75-68.75$ \\
\cline { 3 - 5 } & Heterophyid & No./mm & $2.2 \pm 0.3$ & $1-4$ \\
\hline \multirow{2}{*}{$\begin{array}{c}\text { Mixed } \\
\text { Infection }\end{array}$} & $\begin{array}{c}\text { Diameter } \\
\mu \mathrm{m}\end{array}$ & $82.6 \pm 11.2$ & $37.5-125$ \\
& Nemacercariae & $\begin{array}{c}\text { No./ } \mathrm{mm}^{2} \\
\text { No. larvae/ } \\
\mathrm{mm}^{2}\end{array}$ & $3.3 \pm 0.12$ & $2.67-4$ \\
\hline
\end{tabular}

Histological examination of mixed-infected liver showed invasion of undifferentiated nematode larvae and heterophyid metacercariae to liver parenchyma (Figs. 2, 3) with a remarkable degeneration to the surrounding area.

The histopathological response to infection was represented by a cytoplasmic vacuolation, fatty degeneration, eosinophilic and lymphocytic infiltration, and hepatocellular focal necrosis (Figs. 3-5). In addition to the above, a noticeable damage to pancreatic cells was found (Fig. 5). In a single-infected fish, the severity of histopathological changes in liver was limited as compared to mixed infection (Figs. 6, 7). However, in all cases, there was no inflammatory response to the parasites observed in the tissues.

A high depletion of polysaccharides material was observed in the hepatocytes of mixed infected fish as compared to single one (Figs. 8, 9). Proteins analysis of liver and muscle of examined fish was shown in Table 2. 
In a single-infected fish, protein content was decreased significantly to 113.4 and $195.1 \mathrm{mg} \cdot \mathrm{g}^{-1}$ w.w. in both liver and muscles tissues, respectively, as compared to non-infected tissues. In mixed-infected fish, protein content decreased significantly by 37.25 and 9.02 percentage points, respectively as compared to non-infected and single-infected fish.

Table 2

Protein contents $\left(\mathrm{mg} \cdot \mathrm{g}^{-1}\right)$ of liver and muscles of both non-infected and infected hybrid Oreochromis sp.

\begin{tabular}{ccccc}
\hline \multirow{2}{*}{ Fish state } & \multicolumn{2}{c}{ Liver } & \multicolumn{2}{c}{ Muscles } \\
\cline { 2 - 5 } & $\bar{x} \pm s$ & Range & $\bar{x} \pm s$ & Range \\
\hline $\begin{array}{c}\text { Non- } \\
\text { infected } \\
\begin{array}{c}\text { Single } \\
\text { infection } \\
\text { Mixed }\end{array}\end{array}$ & $113.4 \pm 2.1^{\mathrm{a}}$ & $109.8-117.2$ & $195.1 \pm 3.4^{\mathrm{a}}$ & $188.7-200.4$ \\
infection & $88.3 \pm 2.9^{\text {a, b }}$ & $83.0-93.3$ & $177.5 \pm 6.1^{\text {a, b }}$ & $167.7-188.7$ \\
\hline
\end{tabular}

a Significantly different as compared with normal control.

b Significantly different as compared with corresponding single infection.

As shown in Table 3, lipid content of muscle decreased significantly in both single- and mixed infection $(P<0.01, F=20.11 ; P<0.002, F=162.94$, respectively) as compared to non-infected muscle. Liver lipid content decreased significantly in both infection levels as compared to non-infected tissue $\left(P<0.01\right.$ and $2.4 \cdot 10^{-5} ; F=18.23$ and 496.3, respectively).

Table 3

Lipid content $\left(\mathrm{mg} \cdot \mathrm{g}^{-1}\right.$ wet weight) of liver and muscles of both non-infected and infected hybrid Oreochromis sp.

Examined organ

Fish state

Liver

Muscles

\begin{tabular}{ccccc}
\cline { 2 - 5 } & $\bar{x} \pm s$ & Range & $\bar{x} \pm s$ & Range \\
\hline $\begin{array}{c}\text { Non-infected } \\
\text { Single } \\
\text { infection } \\
\begin{array}{c}\text { Mixed } \\
\text { infection }\end{array}\end{array}$ & $354.88 \pm 12.3$ & $340.68-379.4$ & $81.80 \pm 4.6$ & $74.15-89.97$ \\
\hline
\end{tabular}

a Significantly different as compared with normal control.

b Significantly different as compared with corresponding single infection. 
Table 4

Glycogen content ( $\mathrm{mg} \cdot \mathrm{g}^{-1}$ wet weight) of liver and muscles of both non-infected and infected hybrid Oreochromis sp.

Examined organ

Fish state

Liver

Muscles

\begin{tabular}{ccccc}
\cline { 2 - 5 } & $\bar{x} \pm s$ & Range & $\bar{x} \pm s$ & Range \\
\hline $\begin{array}{c}\text { Non-infected } \\
\text { Single }\end{array}$ & $8.61 \pm 0.7$ & $7.83-9.30$ & $3.20 \pm 0.30$ & $2.70-3.6$ \\
$\begin{array}{c}\text { infection } \\
\text { Mixed } \\
\text { infection }\end{array}$ & $5.20 \pm 0.4^{\mathrm{a}}$ & $4.80-5.50$ & $2.38 \pm 0.10^{\mathrm{a}}$ & $2.25-2.6$ \\
\hline
\end{tabular}

a Significantly different as compared with normal control.

$\mathrm{b}$ Significantly different as compared with corresponding single infection.

Table 4 showed that the glycogen resources in the liver were depleted significantly in single- and mixed infection to 5.2 and $3.86 \mathrm{mg} \cdot \mathrm{g}^{-1}$ w.w. as compared to noninfected tissue $\left(8.6 \mathrm{mg} \cdot \mathrm{g}^{-1}\right)(P<0.01, F=28.1 ; P<0.001, F=118.9$, respectively $)$. Significant difference in glycogen content of muscles of both single- and mixedinfected fish was found as compared to non-infected one $(P<0.01, F=17.4$; $P<0.001, F=59.5$ ), respectively).

Table 5 summarized the protein pattern being separated on a SDS-PAGE for liver and muscle of cultured tilapia. There were 23, 23, and 24 bands detected for none-, single-, and mixed-infected fish muscle, respectively (Fig. 10), with appearance and disappearance of some bands. The amount of the enzyme carbonic anhydrase (31.7 $\mathrm{KDa}$ ) slightly decreased in single infection (7.72 percentage points) and recorded more decrease in mixed infection (2.15 percentage points) as compared to non-infected fish (9.4 percentage points). The amount of enzyme gultamic dehydrogenase $(55.5 \mathrm{KDa})$ increased significantly in both single and mixed-infected fish (by 18.1 and 13.1 percentage points, respectively). Oval albumin bands ( $49.7 \mathrm{KDa}$ ) decreased in all infected groups. Trypsin inhibitors $(21.5 \mathrm{KDa})$ disappeared in muscle of mixed-infected fish. 

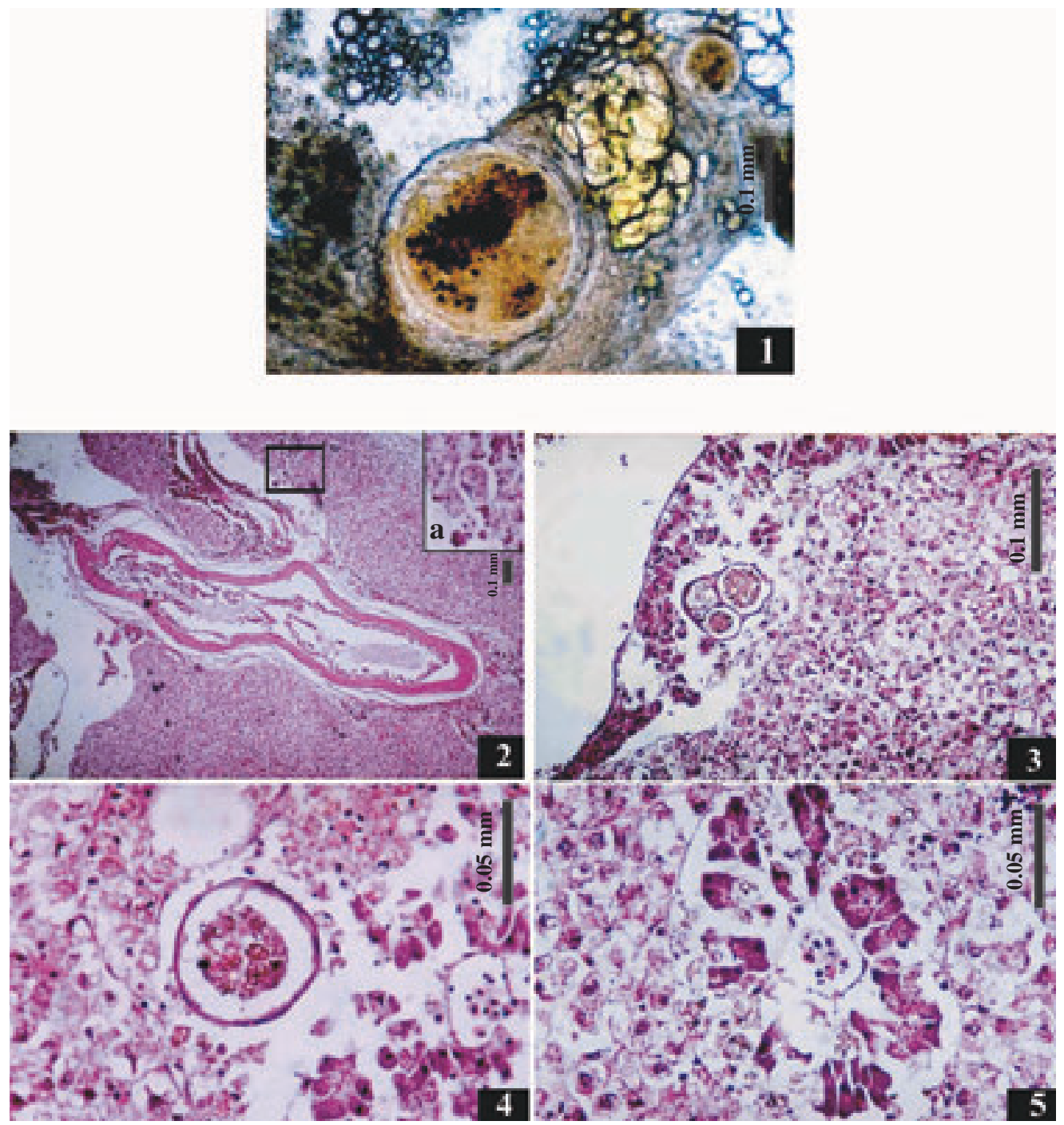

Figs. 1-5. Tissues of hybrid Oreochromis sp. infected with parasites. Fig. 1. Hetrophyid metacercariae in a compressed liver tissue. Fig. 2. Stained section of infected liver showing invasion of undifferentiated nematode larvae and metacercariae (a) to liver parenchyma with a remarkable degeneration to the surrounding area. Fig. 3. Metacercariae in parenchyma with marked degeneration in liver parenchyma. Fig. 4. Section of mixed-infected liver showing cytoplasmic vacuolation, fatty degeneration; leukocytic infiltration, focal necrosis. Fig. 5. Section of liver showing the damage occurred to pancreatic cells 

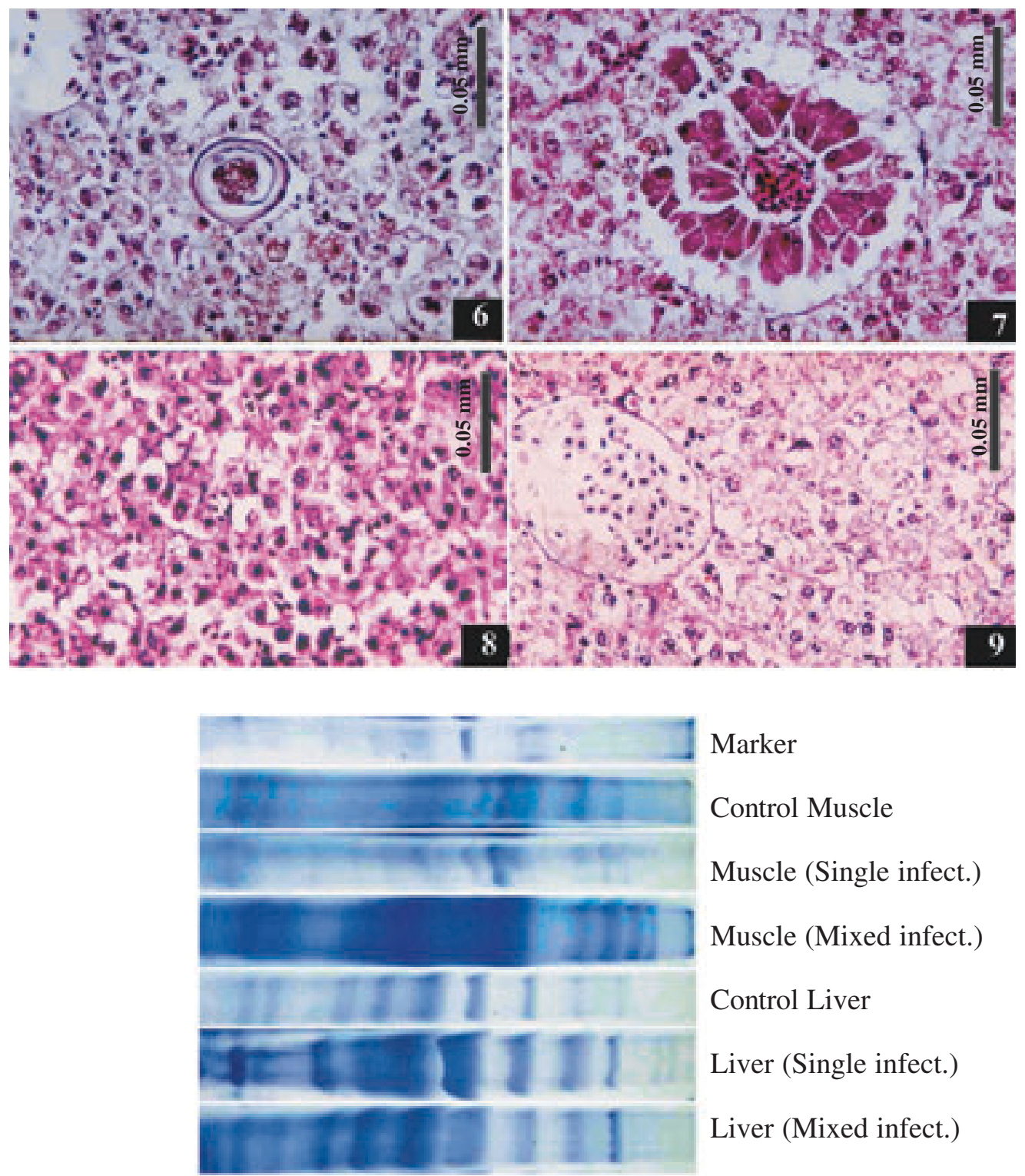

Marker

Control Muscle

Muscle (Single infect.)

Muscle (Mixed infect.)

Control Liver

Liver (Single infect.)

Liver (Mixed infect.)

10

Figs. 6-10. Histopathological and electrophoretic aspects of the pathology of hybrid Oreochromis sp. infected with parasites. Figs. 6-7. Section of metacercariae-infected liver showing that the histopathological alternations were mild as compared to mixed infection. Fig. 8-9. PAS-stained liver sections showing a presence of considerable amount of polysaccharide content and remarkable depletion in this content in single and mixed infection, respectively. Fig. 10. SDS-PAGE pattern of proteins of liver and muscle tissues of non-infected and infected fish 
Table 5

SDS-PAGE Proteins binding pattern of liver and muscle tissues of non-infected and infected hybrid Oreochromis sp.

\begin{tabular}{|c|c|c|c|c|c|c|c|c|c|c|c|c|c|c|}
\hline $\begin{array}{c}\text { Lane } \\
\mathrm{s}\end{array}$ & \multicolumn{2}{|c|}{ Marker } & \multicolumn{2}{|c|}{$\begin{array}{l}\text { Non-infected } \\
\text { fish muscle }\end{array}$} & \multicolumn{2}{|c|}{$\begin{array}{l}\text { Single-infected } \\
\text { fish muscle }\end{array}$} & \multicolumn{2}{|c|}{$\begin{array}{l}\text { Mixed-infected } \\
\text { fish muscle }\end{array}$} & \multicolumn{2}{|c|}{$\begin{array}{l}\text { Non-infected } \\
\text { fish liver }\end{array}$} & \multicolumn{2}{|c|}{$\begin{array}{l}\text { Single-infected } \\
\text { fish liver }\end{array}$} & \multicolumn{2}{|c|}{$\begin{array}{l}\text { Mixed-infected } \\
\text { fish liver }\end{array}$} \\
\hline $\begin{array}{c}\text { Row } \\
\mathrm{s}\end{array}$ & $\begin{array}{c}\text { Mol } \\
\text { wt }\end{array}$ & $\begin{array}{c}\text { amoun } \\
\mathrm{t} \% \\
\end{array}$ & $\begin{array}{c}\text { Mol. } \\
\text { wt }\end{array}$ & $\begin{array}{c}\text { amoun } \\
\mathrm{t} \% \\
\end{array}$ & $\begin{array}{c}\text { Mol. } \\
\text { wt }\end{array}$ & $\begin{array}{c}\text { amoun } \\
t \% \\
\end{array}$ & $\begin{array}{c}\text { Mol. } \\
\text { wt }\end{array}$ & $\begin{array}{c}\text { amoun } \\
\mathrm{t} \% \\
\end{array}$ & $\begin{array}{c}\text { Mol. } \\
\text { wt }\end{array}$ & $\begin{array}{c}\text { amoun } \\
t \% \\
\end{array}$ & $\begin{array}{c}\text { Mol. } \\
\text { wt }\end{array}$ & $\begin{array}{c}\text { amoun } \\
t \% \\
\end{array}$ & $\begin{array}{c}\text { Mol. } \\
\text { wt }\end{array}$ & $\begin{array}{c}\text { amoun } \\
\mathrm{t} \% \\
\end{array}$ \\
\hline $\mathrm{r} 1$ & & & 495.37 & 0.7894 & 490.25 & 0.474 & & & & & 490.25 & 0.738 & 490.25 & 0.187 \\
\hline $\mathrm{r} 2$ & & & 398.2 & 0.5053 & 398.2 & 0.402 & 398.2 & 2.35 & & & 398.2 & 0.534 & 398.2 & 0.162 \\
\hline r3 & & & 323.44 & 0.5031 & 333.69 & 0.464 & 313.51 & 2.1 & & & & & 347.86 & 0.0959 \\
\hline r4 & & & & & 279.63 & 0.404 & 279.63 & 2.36 & & & 288.49 & 0.0838 & 288.49 & 0.183 \\
\hline r5 & 209 & 1.7991 & 209 & 1.0895 & 252.01 & 1.46 & 211.18 & 2.73 & 209 & 1.66 & & & 209 & \\
\hline r6 & & & 173.33 & 0.8969 & 209 & 0.844 & 178.82 & 4.62 & & & 209 & 2.09 & 209 & 4.8 \\
\hline $\mathrm{r} 7$ & & & & & 159.49 & 3.69 & 128.21 & 1.11 & & & & & & \\
\hline r8 & 112 & 1.8379 & 105.86 & 6.1825 & 105.86 & 2.69 & 105.86 & 3.99 & 105.86 & 3.23 & 105.86 & 5.41 & 105.86 & 4.78 \\
\hline r9 & & & 98.739 & 1.9263 & & & 98.413 & 0.682 & & & & & 98.739 & \\
\hline $\mathrm{r} 10$ & & & 84.77 & 1.271 & 84.77 & 0.245 & 92.097 & 0.102 & 84.77 & 7.25 & 84.77 & 6.4 & 84.77 & 4.39 \\
\hline r11 & 83.1 & 4.9359 & 68.975 & 5.1157 & 65.836 & 3.55 & & & & & & & 68.975 & \\
\hline r12 & 55.5 & 11.479 & 52.394 & 10.598 & 52.394 & 18.1 & 52.394 & 13.1 & & & & & 52.394 & \\
\hline r13 & 49.7 & 8.1847 & 45.749 & 2.7197 & 45.749 & 3.09 & 45.749 & 2.51 & 45.749 & 13.3 & 45.749 & 12.9 & 45.749 & 5.67 \\
\hline r14 & & & 37.634 & 2.645 & 36.537 & 2.1 & 38.308 & 0.681 & & & & & 37.634 & \\
\hline $\mathrm{r} 15$ & 31.7 & 13.575 & 31.233 & 9.3991 & 31.233 & 7.72 & 31.233 & 2.15 & 31.233 & 23.3 & 31.233 & 14.4 & 31.233 & 15.1 \\
\hline $\mathrm{r} 16$ & & & 29.554 & 61.197 & & & 29.634 & 7.48 & & & & & 29.554 & \\
\hline r17 & & & & & 28.268 & 3.64 & & & 28.04 & 9.51 & 27.965 & 5.3 & 27.553 & 8.99 \\
\hline $\mathrm{r} 18$ & & & 26.892 & 0.9646 & & & 27.074 & 2.61 & & & & & 26.892 & \\
\hline r19 & & & & & 26.142 & 1.58 & 26.283 & 1.43 & 26.177 & 2.92 & & & 25.931 & 0.273 \\
\hline $\mathrm{r} 20$ & & & 25.481 & 0.3251 & & & 25.481 & 0.359 & 25.481 & 3.59 & 25.481 & 2.19 & 25.481 & \\
\hline $\mathrm{r} 21$ & & & & & & & & & & & 25.038 & 4.1 & 25.106 & 5.18 \\
\hline $\mathrm{r} 22$ & & & 24.143 & 0.0384 & 24.143 & 0.958 & 24.143 & 0.0062 & 24.143 & 0.343 & & & 24.143 & 0.0344 \\
\hline $\mathrm{r} 23$ & & & 22.691 & 1.9599 & 21.91 & & 21.91 & 9.27 & & & & & 21.91 & 0.8 \\
\hline r24 & 21.5 & 5.6303 & 19.801 & 8.5298 & & 4.04 & & & 21.149 & 4.95 & 19.801 & 2.63 & 20.718 & 0.288 \\
\hline r25 & 17.5 & 14.352 & 15.531 & 11.379 & 16.863 & 4.04 & 15.531 & 8.27 & 15.531 & 6.82 & 15.531 & 8.41 & 15.531 & 3.21 \\
\hline $\mathrm{r} 26$ & & & & & 14.421 & 10.5 & 13.897 & 4.16 & & & & & & \\
\hline r27 & & & 13.613 & 3.0214 & 13.118 & 7.14 & & & 13.281 & 1.32 & & & 13.064 & 4.69 \\
\hline $\mathrm{r} 28$ & & & 11.982 & 2.1094 & 11.982 & 5.59 & 11.982 & 5.05 & 11.982 & 1.03 & 11.982 & 7.75 & 11.982 & 5.36 \\
\hline r29 & & & 10.163 & 0.1755 & 10.417 & 2.56 & 10.417 & 0.335 & 10.766 & 2.43 & & & 10.59 & 3.35 \\
\hline $\mathrm{r} 30$ & & & & & & & 8.763 & 0.0634 & & & & & & \\
\hline Sum & & 61.794 & & 78.342 & & 82.5 & & 77.6 & & 81.7 & & 72.9 & & 67.6 \\
\hline $\begin{array}{l}\text { In } \\
\text { lane }\end{array}$ & & 100 & & 100 & & 100 & & 100 & & 100 & & 100 & & 100 \\
\hline
\end{tabular}

SDS-PAGE revealed that liver proteins of non-, single-, and mixed-infected fish were separated to 14,14 , and 19 bands, respectively, with remarkable changes in protein bands pattern (Fig. 10).

Myosin H-chain band (209 KDa), was found in non-infected fish liver and disappeared in infected one. Oval albumin band (49.7 KDa) decreased in mixed infection (5.67 percentage points) as compared to non-infected fish (13.3 percentage points). While carbonic anhydrase band in the liver protein $(31.7 \mathrm{KDa})$ significantly decreased in both single and mixed infection (14.4 and 15.1 percentage points, respectively) as compared to the non-infected fish (23.3 percentage points). 
Results showed that $\mathrm{Fe}, \mathrm{Mn}, \mathrm{Cu}$, and $\mathrm{Ni}$ were detected in liver and muscle of all examined fish while there was no evidence for Co. The level of heavy metals of muscles was summarized in Table 6. Generally, concentrations of Fe and Mn were significantly higher in liver than muscle tissues and those of $\mathrm{Cu}$ and Ni were very low as compared to the $\mathrm{Fe}$ and $\mathrm{Mn}$. There was a positive significant correlation between concentrations of $\mathrm{Fe}$ and $\mathrm{Mn}$ and intensity of parasite infection (Table 6).

Table 6

Heavy metals concentration of liver and muscle tissues of non-infected and infected hybrid Oreochromis sp.

\begin{tabular}{|c|c|c|c|c|}
\hline \multirow[t]{2}{*}{ Organs } & \multicolumn{4}{|c|}{ Heavy metals concentration $\left(\mu \mathrm{g} \cdot \mathrm{g}^{-1}\right.$ w.w. $)$} \\
\hline & Element & Non-infected fish & Single-infected fish & Mixed-infected fish \\
\hline \multirow[t]{4}{*}{ Liver } & $\mathrm{Fe}$ & $159.3 \pm 5.2$ & $\begin{array}{c}265.0 \pm 2.2^{\mathrm{a}} \\
\mathrm{r}=0.78\end{array}$ & $\begin{array}{c}388.6 \pm 3.5^{\mathrm{a}, \mathrm{b}} \\
\mathrm{r}=0.76\end{array}$ \\
\hline & Mn & $48.6 \pm 0.7$ & $\begin{array}{c}91.0 \pm 1.3^{\mathrm{a}} \\
\mathrm{r}=0.52\end{array}$ & $\begin{array}{c}110.9 \pm 0.3^{\mathrm{a}, \mathrm{b}} \\
\mathrm{r}=0.93\end{array}$ \\
\hline & $\mathrm{Ni}$ & $0.075 \pm 0.01$ & $0.12 \pm 0.01$ & $0.11 \pm 0.03$ \\
\hline & $\mathrm{Cu}$ & $0.47 \pm 0.1$ & $0.41 \pm 0.001$ & $0.39 \pm 0.02$ \\
\hline \multirow[t]{4}{*}{ Muscle } & $\mathrm{Fe}$ & $55.1 \pm 2.7$ & $\begin{array}{c}72.1 \pm 0.9^{\mathrm{a}} \\
\mathrm{r}=0.92\end{array}$ & $\begin{array}{c}106.6 \pm 1.5^{\mathrm{a}, \mathrm{b}} \\
\mathrm{r}=0.99\end{array}$ \\
\hline & $\mathrm{Mn}$ & $79.90 \pm 0.2^{\mathrm{a}}$ & $\begin{array}{c}79.90 \pm 0.2^{\mathrm{a}} \\
\mathrm{r}=0.88\end{array}$ & $\begin{array}{c}96.68 \pm 8.9 \\
r=0.95\end{array}$ \\
\hline & $\mathrm{Ni}$ & $0.063 \pm 0.01$ & $0.05 \pm 0.01$ & $0.05 \pm 0.02$ \\
\hline & $\mathrm{Cu}$ & $0.21 \pm 0.1$ & $0.34 \pm 0.01$ & $0.27 \pm 0.01$ \\
\hline
\end{tabular}

a Significantly different as compared with normal control.

b Significantly different as compared with corresponding single infection.

$\mathrm{r}$, Spearman correlation coefficients, showing principal interactions in explaining data variation between heavy metals concentration and intensity of helminth infection.

\section{DISCUSSION}

Fish diseases and histopathology, with a broad range of causes, are increasingly being used as indicators of environmental stress since they provide a definite biological end-point of historical exposure (Stentiford et al. 2003). Wild fish have greeter parasite diversity but with lower population abundance and the reverse is true for cultured fish (Lio-Po and Lim 2002). Consequently, the present study revealed that only undifferentiated nematode larvae and/or heterophyid metacercariae parasitized the liver of a high percentage of examined cultured tilapia. The infections resulted in changes in histological architecture of the liver and depletion in hepatic glycogen reserves, total lipids, and protein. Muscle biochemical complements were also affected. In this regard, histopathological alterations due to infection of fresh water fishes with helminthes parasites were variable and almost potentially pathogenic in 
heavy infection (Taraschewski 2000) and this was in accordance with our results. In addition, Zaghloul et al. (2001) pointed out that alterations of the metabolic pathways of fish can be by a variety of biological and physiological factors.

Dramatic changes of muscle and liver composition (protein and enzyme expression) due to helminth infection were in three main ways; the disappearance of some protein bands, fading away of some existing bands or appearance of new bands, it also affected the relative quantities of protein fraction either by being increase or decrease. However, this fluctuation in protein bands might be considered as a reflection of stressor impact on ribosome and RNA levels and consequently on protein synthesis (Guyton 1961, de Bruin 1976).

Results showed that metal concentrations ( $\mathrm{Fe}$ and $\mathrm{Mn}$ ) were higher in the liver than in the muscle as the target tissues of heavy metals are the tissues of high metabolic activity (Canli et al. 1998). Sorensen (1991) reported that concentration of heavy metal does not depend only on the structure of the organ but also on the interaction between the particular metal and the target organ. Consequently, results highlighted on a possible positive correlation between the level of heavy metals and intensity of infection taking in consideration a fixed size class of examined fish, since size may be an important factor in biochemical content and heavy metals concentration of aquatic animals (Sures et al. 1997, Sures 2001). Low concentrations of Ni and absence of Co in the muscle and liver of fish was not surprising because aquaculture is a system organized to constitute an optimal environment, in contrast to wild and feral fish that generally face human impact (Watson and Yanong 2002). The heavy metal levels recorded in this study were lower than the permissible limits for human consumption (Anonymous 1981, Ellen et al. 1990).

In conclusion, the helminth infection had an impact on condition and health of cultured tilapia. However, the histopathology, biochemical changes, and the protein fractions recorded in this study were taken into account in elevating the response of fish to stressors where parasitism could be adversely affect metabolism of fish.

\section{REFERENCES}

Anonymous, 1981. Manganese. Environmental Health Criteria 17, World Health Organisation, Geneva.

Arthur J.R., Lumanlan-Mayo S., 1997. Checklist of the parasites of fishes of the Philippines. FAO Fisheries Technical Paper 369.

de Bruin A.D., 1976. Biochemical toxicology of environmental agents. Elsevier, New York.

Canli M., Ay Ö., Kalay M., 1998. Levels of heavy metals $(\mathrm{Cd}, \mathrm{Pb}, \mathrm{Cu}, \mathrm{Cr}$ and $\mathrm{Ni})$ in tissues of Cyprinus carpio, Barbus capito and Chondrostoma regium from the Seyhan River, Turkey. Turkish Journal of Zoology 22: 149-157. 
Carroll N.V., Longley R.W., Roe J.H., 1956. The determination of glycogen in liver and muscle by use of anthrone reagent. Journal of Biochemistry 220: 583-593.

Ellen G., Egmond E., van Loon J.W., Sahertian E.T., Tolsma K. et al. (1990). Dietary intakes of some essential and non-essential trace elements, nitrate, nitrite, and $\mathrm{N}$ nitrosamines, by Dutch adults: estimated via a 24-hour duplicate portion study. Food Additives and Contaminants 7: 207-221.

Esch G.W., Fernandez J.C., 1993. A functional biology of parasitism: ecological and evolutionary implications. Chapman and Hall, London.

Etienne M., Jérôme M., Fleurence J., Rehbein H., Kündiger R., Yman I.M., Ferm M., Craig A., Mackie I., Jessen F., Smelt A., Luten J., 1999. A standardized method of identification of raw and heat-processed fish by urea isoelectronic focusing: a collaborative study. Electrophoresis 20: 1923-1933.

Fijan N., 1999. Spring viraemia of carp and other viral diseases and agents of warm-water fish. pp. 177-244. In: Woo P.T.K., Bruno D.W. (eds.) Fish diseases and disorders. Volume 3. Viral, bacterial and fungal infections. CABI Publishing, Wallingford, UK.

Guyton A.C., 1961. Textbook of medical physiology 2nd edition. Saunders Philadelphia and London.

Hamza-Chaffai H.A., Amiard J.C., Cosson R.P., 1999. Relationship between metallothioneins and metals in a natural population of the clam, Ruditapes decussatus from Sfax coast: a non-linear model using Box-Cox transformation. Comparative Biochemistry and physiology C 123: 153-163.

Hrubec T.C., Cardinale J.L., Smith S.A., 2000. Hematology and plasma chemistry reference intervals for cultured tilapia (Oreochromis hybrid). Veterinary Clinical Pathology 29 (1): 7-12.

Kabata Z., 1985. Parasites and diseases of fish cultured in the tropics. Taylor and Francis, Philadelphia.

Lim L.H.S., 1990. Silurodiscoides Gussev, 1961 (Monogenea: Ancyrocephalidae) from Pangasius sutchi Flowler, 1931 (Pangasiidae) cultured in peninsular Malaysia. Raffles Bulletin of Zoology 38: 55-63.

Lim L.H.S., 1991. Fish parasites in integrated farming systems in peninsular Malaysia Proceedings of the FAO/IPT international workshop on integrated livestock-fish production systems. Kuala Lumpur, Malaysia, December 16-20, 1991. pp. 127-134.

Lio-Po G.D., Lim, L.H.S., 2002. Infectious diseases of warmwater fish in fresh water. pp. 231-281. In: Woo P.T.K., Bruno D.W., Lim L.H.S. (eds.). Diseases and disorders of finfish in cage culture. CABI Publishing, Wallingford, UK.

Mackie I., Craig A., Etienne M., Jérôme M., Fleurence J., Jessen F., Smelt A., Krujit A., Malmheden-Yman I., Ferm M., Martinez I., Perez-Martin R., Piñeiro C., Rehbein H., Kündiger R., 2000. Species identification of smoked and gravad fish products by sodium dodecylsulphate polyacrylamide gel electrophoresis urea isoelectric focusing and native isoelectric focusing: A collaborative study. Food Chemistry 71: 1-7.

Paperna I., 1991. Diseases caused by parasites in the aquaculture of warm water fish. Annual Review of Fish Diseases 1: 155-194.

Paperna I., 1996. Parasites, infections and diseases of fishes in Africa. An update. CIFA Technical Paper 31. 
Popma T., Masser M., 1999. Tilapia: life history and biology. Southern Regional Aquaculture Center Publication 283.

Rottmann R.W., Francis-Floyd R., Durborow R., 1992. The role of stress in fish disease. Southern Regional Aquaculture Center Publication 474.

Smedes F., Thomasen T.K., 1996. Evaluation of the Bligh and Dyer lipid determination method. Marine Pollution Bulletin 32 (8/9): 681-688.

Sorensen J.L., 1991. 133Xenon absorption into rubber-protected portable cadmium telluride $(\mathrm{CdTe}(\mathrm{Cl}))$ detectors invalidating the 133 Xenon washout method for measurement of cutaneous and subcutaneous blood flow rates in man. Acta Physiologica Scandinavica (603): 125-131.

Stentiford G.D., Longshaw M., Lyons B.P., Jones G., Green M., Feist S.W., 2003. Histopathological biomarkers in estuarine fish species for the assessment of biological effects of contaminants. Marine Environmental Research 55 (2): 137-159.

Sures B., 2001. The use of fish parasites as bioindicators of heavy metals in aquatic ecosystems: a review Aquatic Ecology 35 (2): 245-255.

Sures B., Taraschewski H., Rydlo M., 1997. Intestinal fish parasites as heavy metal bioindicators: a comparison between Acanthocephalus lucii (Palaeacanthocephala) and the zebra mussel, Dreissena polymorpha. Bulletin of Environmental Contamination and Toxicology 59: 14-21.

Taraschewski H., 2000. Host-parasite interactions in Acanthocephala: a morphological approach. Advances in Parasitology 46: 1-179.

Watson C., Yanong R. P., 2002. Use of copper in freshwater aquaculture and farm ponds. Fact Sheet FA-13, Institute of Food and Agricultural Sciences, University of Florida.

Zaghloul K.H., Abd El-Monem S., Fayed H.M., Mohamed H.A., 2001. Fish parasites as biological indicators of pollution with heavy metals. Journal of Union of Arab Biologists A 15: 533-561. 
